\title{
ÉSZAK-DUNÁNTÚLI VÁLLALKOZÓI ELIT ELVÁRÁSAI A SZÉCHENYI ISTVÁN EGYETEMMEL ÉS HALLGATÓIVAL SZEMBEN
}

\author{
(The Expectations of the North-Transdanubian Business Elite \\ towards the István Széchenyi University and its Students)
}

\section{KOVÁCS ZSOLT - TAMÁNDL LÁSZLÓ - FILEP BÁLINT}

\begin{abstract}
Kulcsszavak:
felsőoktatás munkaerōpiac friss diplomások munkáltatói felmérés

Az elitté válás egyik eszköze a felsöoktatás, amelyet manapság egyre több kritika ér. A tömegképzés kialakulása az elmúlt másfél-két évtizedben hozzájárult ahhoz, hogy a diplomás végzettség egyre több területen elértéktelenedjen, és mint az elitté válás eszköze egyre inkább háttérbe szoruljon. Ennek okai összetettek, jelen tanulmányban az összesre nem kivánunk kitérni, elsósorban a Széchenyi Istuán Egyetem és a munkaeröpiac kapcsolatát vizsgáljuk a 2009 nyarân egy 50 elemü mintán lefolytatott mélyinterjús vizsgálat alapján. Jelen tanulmányban a témához kapcsolódóan emelünk ki néhány eredményt a kutatásból.
\end{abstract}

\section{Bevezetés}

A jövő értelmiségének és elitjének egyik kiemelt forrása a felsőoktatás, amely a kilencvenes évek elejétől jelentős változáson ment keresztiil.

Ennek okai igen széles körủek: rendszerváltás, intézményi autonómia iránti harc, hallgatói demokratikus képviselet létrejötte, magánegyetemek alakulása, normatív finanszírozás következményei, tandíj bevezetése, majd eltörlése, a közelmúltban lezajlott integráció, a kreditrendszer bevezetése. A hallgatói létszámok megsokszorozódtak, s a kilencvenes évek elejétől egészen 2005-ig a felsőoktatásban részt vevő hallgatók száma közel megnégyszereződött, miközben az oktatók létszáma, a kollégiumi féróhelyek, a tantermek befogadóképessége nem a megfelelő arányban változott (ÁSZ 2009).

A központi támogatás normatív jellegü, ezért megindult a harc a hallgatókért. A képzési normatíva lassan és kismértékben történö emelése (illetve csökkentése) arra kényszerítette az intézményeket, hogy minél magasabb hallgatói létszámmal dolgozzanak, már-már túllépve kapacitásaikat. A kormányzat, a MAB (Magyar Akkreditációs Bizottság) követelményrendszerében egyre nagyobb hangsúlyt kap a minőségbiztosítás, a minôségi oktatás. Ehhez viszont - a teljesség igénye nélkuil megfelelő oktatói háttér (minősített oktatók, kutató oktatók), müszerpark, oktatási segédletek, jegyzetek, jól felszerelt kỏnyvtár, nyugodt légkörú helyiségek szuikségesek.

A minőségi oktatás viszont nem csak az akkreditációs folyamat szempontjából fontos tényezö. Megindult a verseny a felsőoktatási intézmények között a hallgatókért. 


\section{Kovács Zsolt-Tamándl László-Filep Bálint TÉT XXIV. évf. 2010 @ 2}

Ez több tényezönek a közös hatása. Egyrészt elindult egy demográfiai csökkenés, amely a felsőoktatásba jelentkezők számának csökkenését jelenti. Ezt erösíti az is, hogy míg a felnőttképzésben a kilencvenes években, illetve évtizedünk kezdetén a felvételi számok nőttek, köszönhetően többek között annak, hogy a korábban a középiskolában végzettek közül, akiknek nem adatott meg a lehetőség továbbtanulni, azok ezt most megtehették, addig 2004-2005-töl csökkenő tendencia figyelhetö meg, hiszen a társadalomból ez az ún. tartalék elfogyott. A versenyben részt vevó intézmények száma szintén megnött, ma Magyarországon 71 kisebb-nagyobb állami, egyházi, illetve magán felsőoktatási intézmény működik. Ezt a problémát az évtized elején végbemenő integrációs törekvések sem tudták megoldani. Így lehetséges az például, hogy gazdasági képzés több mint 30 intézményben folyik.

Összegezve ezen folyamatokat, látható az az irány, hogy a korábbi alacsony létszámú elitképzés irányából a felsőoktatás elindult a tömegképzés irányába, s így az elithez tartozás kialakulásának több fontos tényezője közül, amelyeket jelen tanulmányban nem vizsgáltunk, az oktatás és azon belïl is a felsőoktatás erősen háttérbe szorult.

De ki a felelős a kialakult helyzetért, a tömegképzés kialakulásáért, az egyes képzési területek közötti aránytalan hallgatói eloszlásért, egyszóval a diplomák devalválódásáért? Itt értékvesztés alatt elsősorban az értendő, hogy a megszerzett diploma társadalmi státusa csökkent, illetve hatása az egyén társadalmi státusának pozitív irányú befolyásolására gyengült.

A kérdésre nem könnyű választ adni, mivel a felsőoktatás speciális terület, és az ezt a területet alakító tényezők, szereplők véleményünk szerint mind tehetnek a kialakult helyzetről. A szereplőket az 1. ábrán tüntettük fel:

- Oktatási kormányzat: szerepe és súlya egyértelmü a felsőoktatásban. A felsöoktatási intézmények bizonytalan finanszírozása, az intézmények nagy száma és azok minősítési rendszere, a hallgatói felvételi döntések kisebb mértékü befolyásolása az új felvételi rendszer által, az egységes oktatási rendszerre, illetve a felsőoktatásra vonatkozó stratégiának a hiánya mind olyan tényezők, amelyek a fent leírt folyamatokat közvetve erösítik. Ezt támasztja alá a 2009 júniusában publikált Állami Számvevőszéki jelentés is: ,az OKM a stratégiai célkitüzések hiányában nem készítette el a felsőoktatás rendszerre fejlesztési terveit, beleértve a középtávú fejlesztési tervet. A stratégiai megalapozottság hiányát jelzi, hogy az új Ftv-t már a hatálybalépés évében (2006.), majd azt követóen 2007. és 2008. években is módosították." (ÁSZ 2009, 13)

- Felsőoktatási intézmény: a finanszírozási és jogszabályi környezetnek megfelelően elmozdultak a tömegképzés irányába, és egy extenzív fejlesztésbe kezdtek, melynek forrásai a 21. század első évtizedének második felére kimerülttek. Az expanzió hatására a korábbi oktatási színvonalat nem tarthatták, mivel kapacitásuk mind a humán erőforrás, mind pedig a tárgyi feltételek terén nem követték a hallgatói létszám növekedését. Bizonyos képzési területeket és szakokat, amelyek divatossá váltak, a szerényebb piaci és társadalmi igények ellenére bevezettek, s képeztek, képeznek szinte öncélúan diplomásokat a társadalom költségein. 
- Hallgató: a pályaválasztásuk során jellemzően ritkán veszik figyelembe a munkaerö-piaci trendeket, és a kisebb ellenállás irányába haladva választanak olyan szakot, amely elvégzése számukra kevesebb eröfeszítésbe kerül. A kreditrendszerböl adódóan szinte csak saját anyagi lehetőségeik szabnak gátat a tanulmányaik folytatásának, így egy 6 féléves képzést akár 12 félévig is elnyújthatnak. A rugalmas óraválasztásnak köszönhetően az intézményben töltött idejüket a minimálisra csökkentik, így az egyetemen, föiskolán eltöltött éveik alatt a közösségi, tudományos, kulturális és sport tevékenységek adta lehetőségeket csak korlátozottan használják ki, nem fejlesztve ezzel saját társadalmi tőkéjüket.

- Hallgatók szülei: elsősorban a hallgatók orientálásában, illetve nemorientálásában van óriási felelősségük.

- Munkáltatók: szerepük abban rejlik, hogy munkaerő igényeiket megfogalmazzák közép, illetve hosszú távon, és ne csak rövid távon. Ez az elvárás a gyorsan változó gazdasági környezetben eléggé kétségesnek tünik. Azonban egy élö és folyamatos kapcsolat a felsőoktatási intézményekkel segíthet viszszajelzéseket adni az intézményekben folyó képzések minöségéröl, a végzett hallgatók munkaerő-piaci sikerességéröl. Ezen visszajelzések ma még eléggé esetlegesek, $\mathrm{s}$ azok felhasználása az intézmények részéröl még kérdéses.

\section{1. ÁBRA}

A felsöoktatás problémája: a diplomák értékvesztése

(The Problem of Higher Education: the Diplomas are Loosing their Value)

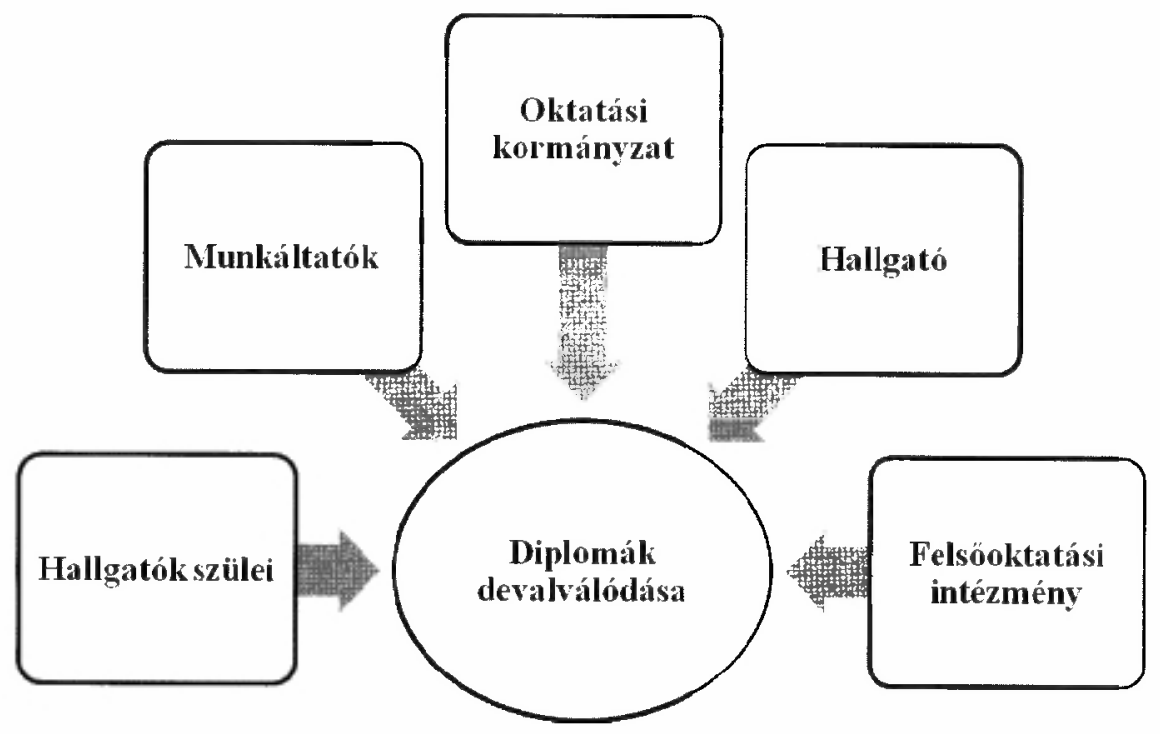

Forrás: Saját szerkesztés. 
Kovács Zsolt - Tamándl László - Filep Bálint : Észak-dunántúli vállalkozói elit elvárásai a Széchenyi István Egyetemmel és hallgatóival szemben. - Tér és Társadalom 24. évf. 2010/2. 93-105. p.

Jelen tanulmány a fent felsorolt tényezők közül a felsőoktatási intézmény és a munkáltatók kapcsolatával foglalkozik, melynek alapja egy 2009 nyarán lefolytatott kutatás. A Széchenyi István Egyetem és az Educatio Kht. együttmúködésében lefolytatott vizsgálat egy olyan munkáltatói mélyinterjúkon alapuló kutatás, amely az intézményi tényezők és a regionalitás szerepét elemzi a pályakezdők munkavállalási jellemzöiben. A felsőoktatás területén, illetve a Széchenyi István Egyetemen végzett korábbi vizsgálatok szempontjait vettük figyelembe a kutatás kiindulásakor (Rechnitzer-Hardi 2003; Rechnitzer-Smahó 2008), illetve olyan tudományos értekezéseket elemeztünk, amelyek a felsőoktatás és a régiók kapcsolatát vizsgálták itthon és külföldön (Majó 2000; Boucher-Conway-Meer 2003; Kasza 2007; Kuráth 2007). A vizsgálat eredményeként - a munkáltatói kutatásoktól elvárhatóan - részletes képet kapunk a Széchenyi István Egyetem (SZE) vonzáskörzetébe tartozó munkáltatók végzett hallgatókkal kapcsolatos igényeiröl és tapasztalatairól, az intézményi együttmüködés iránti igényeiről, illetve ehhez kapcsolódóan a regionális szempontok súlyáról.

A pilot kutatás célja volt továbbá egy olyan kutatási program-modell felépítése, amely részletezi és illusztrálja azokat a lépéseket és módszertani megfontolásokat, amelyek mentén a jövőben a felsőoktatási intézmények a számukra releváns munkáltatói környezetben diplomás pályakövetési vizsgálatokat végezhetnek. Mindemellett a kutatás célja volt elméletibb irányultságú következtetések levonása is a munkaerö-piaci kutatások és a regionalitás kapcsolatát illetően. A pályakövetés munkaerő-piaci vonatkozásainak jelentöségét mutatja az a tény, hogy Magyarországon az ez idáig felsöoktatási intézményi körben lezajlott pályakövetéses vizsgálatok motivációiban a munkaerőpiacról szerzendő információk fontossága kiemelkedő jelentôséggel bír (Horváth 2008). A képzési területi szempontok beemelésének indokoltságát a vizsgálatba alátámasztja az a tény is, mely szerint az intézményi pályakövetéses vizsgálatokon belül a munkaerö-piaci státusra vonatkozó kérdések arányát erősen befolyásolja az intézmény szakterülete, piaci orientáltsága.

\section{Módszertan}

A Széchenyi István Egyetem Karrier és Öregdiák Irodája az Educatio Kht.-val közösen egy 50 elemủ mélyinterjús pilot kutatást végzett 2009 nyarán. A felmérés indításakor a célok megfogalmazása után a módszertan, illetve a minta felállítása során a következő tapasztalatokat gyüjtöttük össze. A minta kialakításakor alapvetően a Széchenyi István Egyetem eddig meglévő kapcsolatrendszeréből indultunk ki, amely 383 partnert tartalmazott. Ezekkel a cégekkel az intézménynek már volt legalább egyszer valamilyen kapcsolata, így ez a kapcsolatfelvételt és a válaszadási hajlandóságot is pozitívan befolyásolta, egy-két esetet leszámítva szinte mindenhol pozitívan fogadták megkeresésünket. A minta kialakításánál alapvetően egy korábbi felmérés eredményeiből indultunk ki, amelyet a 2008-ban végzett hallgatók körében a 
Kovács Zsolt - Tamándl László - Filep Bálint : Észak-dunántúli vállalkozói elit elvárásai a Széchenyi István Egyetemmel és hallgatóival szemben. - Tér és Társadalom 24. évf. 2010/2. 93-105. p.

TÉT XXIV. évf. 2010 @ 2

Észak-dunántúli vállalkozói elit ....

97

végzés pillanatában készített a Karrier és Öregdiák Iroda. Ez alapján jól látható, hogy a Széchenyi István Egyetem alapvetően egy erős, regionális hatásokkal és szerepkörrel müködő intézmény: hallgatóinak több mint 2/3-a a Nyugat-dunántúli régióból, illetve a Balaton vonalától északra fekvő közép-dunántúli területről érkezik (2. ábra).

Ezért a minta kialakításánál a Nyugat-dunántúli és Közép-dunántúli régió munkaerő-piaci arányait vettük kiindulási alapul. Továbbá ezt a szempontot támasztja alá a felmérés egy másik eredménye, mely szerint a végzettjeink túlnyomó többsége (kb. 63\%) Györben, illetve a régióban kíván elhelyezkedni.

\section{2. ÁBRA}

Az Egyetem hallgatóinak megoszlása állandó lakhely szerint 2008-ban

(The Distribution of the Students According to their Place of Residence)

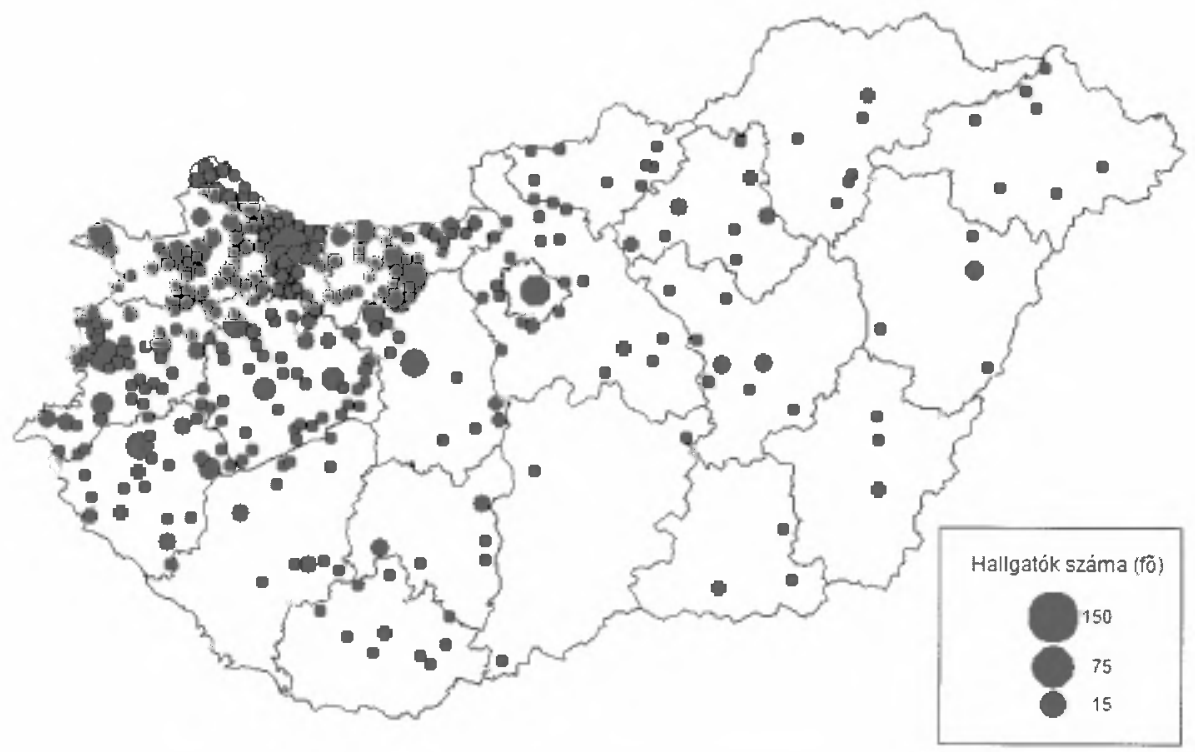

Forrás: Felmérés a Széchenyi István Egyetem végzös hallgatóinak körében (2008).

A régió értelmezésekor azzal a problémával találkoztunk, mint amivel a korábbi pályakövetéses vizsgálatokkor, hogy az Egyetem alapvetően regionális hatásokkal bíró szervezet a beiskolázást, illetve a végzett hallgatók elhelyezkedését illetỏen, de ez nem vetíthetó egy statisztikai-tervezési régióra, mint pl. a Nyugat-dunántúli régió, hanem sokkal inkább a Balaton vonalától északra fekvő területek által meghatározott régió az, amely az intézménnyel ténylegesen interakcióban áll. Ezért a minta kialakításakor a Nyugat-dunántúli és Közép-dunántúli régió foglalkozás-statisztikai adatait vettük figyelembe. A kis elemszám miatt a minta reprezentativitásában a gazdasági szektorok, illetve ágazatok szerinti bontást érvényesítettük. További szempontokat, mint pl. területi elhelyezkedés, szervezet mérete a reprezentativitásba a kis elemszám miatt nem építettuik be, viszont igyekeztünk a teljes spektrumot mind méret, mind elhelyezkedés szerint lefedni. A képzési teruilet szerinti bontást szintén nem alkalmaztuk 
Kovács Zsolt - Tamándl László - Filep Bálint : Észak-dunántúli vállalkozói elit elvárásai a Széchenyi István Egyetemmel és hallgatóival szemben. - Tér és Társadalom 24. évf. 2010/2. 93-105. p.

98 Kovács Zsolt-Tamándl László-Filep Bálint TÉT XXIV. évf. 2010 四 2

a minta kialakításakor, mivel míg az Egyetem oldaláról egyértelmúen meghatározható a képzési területi arány, addig ez vállalati oldalról már nem értelmezhető.

A kérdőív kialakításakor azt négy fő részre osztottuk. Az elsőben a szervezetre vonatkozó általános adatokat rögzítettuik, majd ezt három tematikus rész követte.

- Az első célja a munkaerőpiac regionális szempontjainak vizsgálata;

- a második rész a Széchenyi István Egyetem, illetve a partnere közötti együttműködés mennyiségi és minöségi szempontjait;

- míg a harmadik rész a munkáltatóknak az intézményben végzett hallgatókkal szembeni elvárásait vizsgálta.

A megkérdezettek körének kialakításakor az Educatio Kht. iránymutatását vettük alapul, amely az MKIK GVI kutatás által használt definíciót javasolta: a megkérdezett ,a személyzeti ügyekért felelös vállalatvezető vagy - kisebb cégek esetében az általános vállalati vezetô" (Diplomás... 2007, 16) (1. táblázat).

\section{TÁBLÁZAT \\ Megkérdezettek csoportositása \\ (The Grouping of the Interviewees)}

\begin{tabular}{lc}
\hline \multicolumn{1}{c}{ Megkérdezettek csoportosítása } & Megkérdezettek száma $(f o ̈)$ \\
\hline Szervezet/telephely vezetöje & 33 \\
Személyzeti vezetö & 15 \\
Egyéb & 2 \\
Végösszeg & 50 \\
\hline
\end{tabular}

Forrás: Saját szerkesztés.

A megkérdezettek közuil 33-an a szervezet vezetöi csoportjába tartoznak (szervezet általános, gazdasági vezetöi), 15-en a szervezeten belül a munkaügyi területért felelősek, illetve két esetben nem sikerült a megfelelö vezetö személyt elérnünk, ezért munkatársuk volt segítségünkre.

\section{A kutatás fókuszpontjai, eredményei}

A vizsgálat első felében arra kerestük a választ, hogy tudják-e a megkérdezett szervezetek értelmezni a regionális munkaeröpiacot, mint egységet. A megkérdezettek 70\%-a úgy gondolja, hogy létezik és értelmezhető a regionális munkaerőpiac fogalma. Abban viszont már nagyon eltérő képet mutatnak, hogy ki hogyan értelmezi azt, mit jelent a régió számára, egyáltalán saját szervezete esetében releváns-e. Több esetben megfogalmazódott az a vélemény, hogy a mai statisztikai régiók gazdasági és munkaerő-piaci szempontból nem értelmezhetőek a gazdasági szervezetek számára, saját szempontjukból az általuk használt régió fogalom határa a saját hatókörük határa. A válaszadók többsége érzékel régión, illetve országon átnyúló munkaerő-piaci kapcsolatokat. Ezeket véleményük szerint elsősorban a hiányszakmák, fizetési igények mellett a helyi gazdasági erỏ motiválja, tehát, hogy a múködő tőke mennyire van koncentrálva. Nyílván ez meghatározza a munkaerö-keresletet is. 
Kovács Zsolt - Tamándl László - Filep Bálint : Észak-dunántúli vállalkozói elit elvárásai a Széchenyi István Egyetemmel és hallgatóival szemben. - Tér és Társadalom 24. évf. 2010/2. 93-105. p.

TÉT XXIV. évf. 2010 @ 2

Észak-dunántúli vállalkozói elit ....

99

Az országok közötti kapcsolatokat természetesen a térség határmentisége (Szlovákia, Ausztria) nagyban elösegíti és erösíti. Szervezeten belül viszont már inkább csak a multinacionális szervezetekre jellemzỏ a régiókon, illetve határokon átnyúló munkaerö-piaci kapcsolat, elsősorban a speciális ismeretek hiányából adódóan. A regionális szereplök kapcsolatai közül a szakmai kamarákkal, illetve az egyéb szakmai szövetségekkel állnak szorosabb kapcsolatban, míg a Regionális Fejlesztési Ügynökségekkel csak 12\%-uknak van kapcsolata.

A multinacionális vállalatok hatását gazdasági és társadalmi szempontból pozitívan és negatívan is értékelték a megkérdezettek. Pozitív hatásuk elsősorban, hogy beruházásokat, technológiai korszerüsítéseket hajtanak végre. Ezek a vállalatok a helyi és nemzetközi jogszabályok szerint müködnek. Adófizetők, amelyböl a helyi önkormányzat és az állam is profitálnak. Erős az érdekérvényesítő szerepük.

Ugyanakkor negatív hatásként emelték ki, hogy 1-2 kivételtől eltekintve nem fizetik meg a kvalifikált munkaeröt. Szerintük ezeknél a multiknál nem érvényesülnek gyakran az alapvető munkavállalói jogok. Negatívum továbbá az is, hogy jogosulatlan gazdasági előnyt élveznek a hazai versenytársakkal szemben, illetve az esetek többségében az anyavállalatok elszívják a leányvállalatoktól a profitot, vagyis az nem itthon hasznosul, ami nem kedvez a magyar gazdaságnak.

Speciális igényeik közé tartozik az idegen nyelv tudása, továbbá fontos a megbízható és alapos, magas szintủ tudás és tapasztalat, a tudás növelésével kapcsolatosan az új dolgok iránti nyitott attitủd. Minden nagyvállalat azt szeretné, ha az ő speciális igényeihez igazodna az intézmény. Ezért fontosnak tartják a felsőoktatási intézményekkel kialakítandó kapesolatot, hiszen az oktatás annál jobb lesz, minél gyakorlatorientáltabb képzést tud biztosítani. Továbbá fontos szempont a mobilitás, flexibilitás vállalaton belül és kívuil is.

A mikro-, kis- és középvállalkozások gazdasági és munkaerö-piaci szerepükről egységesen úgy vélekednek, hogy a magyar gazdaságban fontos szerepet játszanak, föleg foglalkoztatási szempontból, viszont korlátozottak a lehetőségeik, megélhetésük eléggé nehézkes. Több állami támogatásra lenne szükségük, hogy megerösödjenek, és minőségi terméket állítsanak elő és minőségi szolgáltatásokat nyújtsanak. Ez a munkahelyek megtartása szempontjából is nagy jelentőséggel bír. Érdekeik és igényeik homlokegyenest mások, mint a multinacionális vállalatoknak. Magasan kvalifikált munkavállalókra van szükségük, de őket a multik elvonzzák „szakmunkás munkára" kétszer annyi pénzért. 2-3 év kiképzés után a frissen felvett munkatársak nagy része továbbmegy a $\mathrm{KKV}$-tól a föleg Budapesten lévő cégekhez, ezért a munkatárs kiválasztásakor egyre fontosabb szempontot jelent a helyi kötỏdés, pl. család. A KKV-k saját véleményük alapján nem tudnak annyit fizetni a kvalifikált munkaerőnek, mint egy multi, ezért a munkaerőpiacon hátrányt szenvednek. Képzési igényeiket igazából nehezen tudják meghatározni. Viszont fontos szempont az elméleti tudás mellett és helyett az önállóság, gondolkodás, bátorság, felelősségvállalás, feladatmegoldó képesség. Minőségi oktatást várnak el, nem a papír a kérdés, tehát nem a megszerzett diploma megnevezése a lényeg, hanem a vele megszerzett tudás és gyakorlat. 
Kovács Zsolt - Tamándl László - Filep Bálint : Észak-dunántúli vállalkozói elit elvárásai a Széchenyi István Egyetemmel és hallgatóival szemben. - Tér és Társadalom 24. évf. 2010/2. 93-105. p.

A felmérés során megvizsgáltuk a Széchenyi István Egyetem és gazdasági partnerei, mikro-, kis-, közép- és nagyvállalatok, nonprofit szervezetek és költségvetési szervek közötti kapcsolatrendszert, elsősorban a munkaerö-piaci szempontok alapján (2. táblázat). Megállapítható, hogy az Egyetem kapcsolatban áll a felkeresett partnerek $96 \%$-ával, ez természetesen a mintaválasztásnak is köszönhetö. A megkérdezettek átlagosan 3,84 számú kapcsolatot tartanak fenn az intézménnyel. A kapcsolatok fajtái közül a végzett hallgatók foglalkoztatását, gyakornokok fogadását, közös képzési és kutatási programok lebonyolítását lehet kiemelni.

\section{TÁBLÁZAT}

Kapcsolatok típusa és sokfélesége

(The Type and Variety of the Relationships)

\begin{tabular}{|c|c|c|c|c|c|}
\hline \multirow{2}{*}{ Kapcsolatok típusa } & \multicolumn{5}{|c|}{$\begin{array}{l}\text { Válaszok száma a szervezeti } \\
\text { méret bontásában }(\mathrm{db})\end{array}$} \\
\hline & mikro & kis & közép & nagy & összes \\
\hline végzett hallgatókat alkalmaz & 7 & 4 & 11 & 13 & 35 \\
\hline $\begin{array}{l}\text { gyakornoki programjában részt vesz- } \\
\text { nek az intézmény hallgatói }\end{array}$ & 3 & 3 & 10 & 13 & 29 \\
\hline Karrier Irodával áll kapcsolatban & 4 & 2 & 8 & 11 & 25 \\
\hline egyéb kapcsolat & 6 & 5 & 3 & 5 & 19 \\
\hline diákmunkában alkalmaz hallgatókat & 2 & 3 & 5 & 8 & 18 \\
\hline $\begin{array}{l}\text { szakértői munkákkal bízza meg - } \\
\text { munkakapcsolat }\end{array}$ & 2 & 3 & 5 & 8 & 18 \\
\hline $\begin{array}{l}\text { formális, intézményvezetők közötti } \\
\text { kapcsolat }\end{array}$ & 2 & 4 & 4 & 7 & 17 \\
\hline $\begin{array}{l}\text { támogatja, pl. szakképzési támogatás, } \\
\text { ösztöndíjprogram, közös pályázatok }\end{array}$ & 0 & 1 & 5 & 8 & 14 \\
\hline $\begin{array}{l}\text { közös kutatási programokban vesz } \\
\text { részt }\end{array}$ & 0 & 2 & 5 & 4 & 11 \\
\hline $\begin{array}{l}\text { közös képzési programokban vesz } \\
\text { részt }\end{array}$ & 0 & 0 & 3 & 3 & 6 \\
\hline $\begin{array}{l}\text { Kapcsolattartás formáinak száma } \\
\text { átlagosan }\end{array}$ & 2,89 & 4,50 & 3,47 & 4,44 & 3,84 \\
\hline
\end{tabular}

Forrás: Saját szerkesztés.

$\mathrm{Az}$ intézményről elsősorban még mindig személyes úton kapják a partnerek a legtöbb információt, amely az Egyetem vezetöin, munkatársain keresztül valósul meg. 76\%-uk nyitott továbbá a meglévő együttmúködések fejlesztésére, illetve újak kialakítására elsősorban a gyakornoki programok, közös egyetemi előadások, tananyag és tantervek fejlesztése, közös kutatási programok keretein belül.

A felmérés 3. nagy fejezeteként vizsgáltuk a szervezeteknél a diplomások arányát, illetve a friss diplomásokról alkotott képet, alkalmazásuk előnyeit, hátrányait, a velük szemben támasztott elvárásokat, a munkáltató szervezethez kerülés (bekerülés) módjait, csatornáit. A megkérdezettek közül egy kivételével mindenki elég 
Kovács Zsolt - Tamándl László - Filep Bálint : Észak-dunántúli vállalkozói elit elvárásai a Széchenyi István Egyetemmel és hallgatóival szemben. - Tér és Társadalom 24. évf. 2010/2. 93-105. p.

TÉT XXIV. évf. 2010 - 2

Észak-dunántúli vállalkozói elit ....

101

nagy pontossággal meg tudta határozni a szervezetnél dolgozó diplomások számát. 12\%-uknak viszont már problémát okozott a Széchenyis diplomával rendelkezők számának meghatározása. Alapvetően megfigyelhető, hogy a mintába került szervezeteknél a kisebb szervezetektől a nagyobbak felé haladva csökken a diplomás alkalmazottak száma.

A szervezeteknek csak $8 \%$-ára jellemző, hogy nem fogadnak pályakezdő diplomásokat, $80 \%$-ukra nagyon jellemzö, $12 \%$-ukra pedig kevésbé jellemzö. A válaszadók többsége kiemelte, hogy érdemes diplomás pályakezdőket foglalkoztatni. A foglalkoztatás elönyei közül kiemelkedik az a szempont, mely szerint a pályakezdőknek még nincsenek berögződött rutinjai, teljesen szabadon formálhatóak az adott cég, szervezet elvárásainak, feltételeinek, kultúrájának megfelelöen. Jellemző rájuk a rugalmasság, mobilitás. Kiemelkedő szempont továbbá a friss szakmai tudás, a fiatalos lendület, motiváció és bizonyítási vágy (3. ábra), amely által magának a szervezetnek is új lendületet adhat a friss diplomás.

\section{3. ÁBRA}

Friss diplomások elönyei, az adott válaszok arányában

(The Advantages of Employing New Graduates, in the Ratio of the Given Answers)

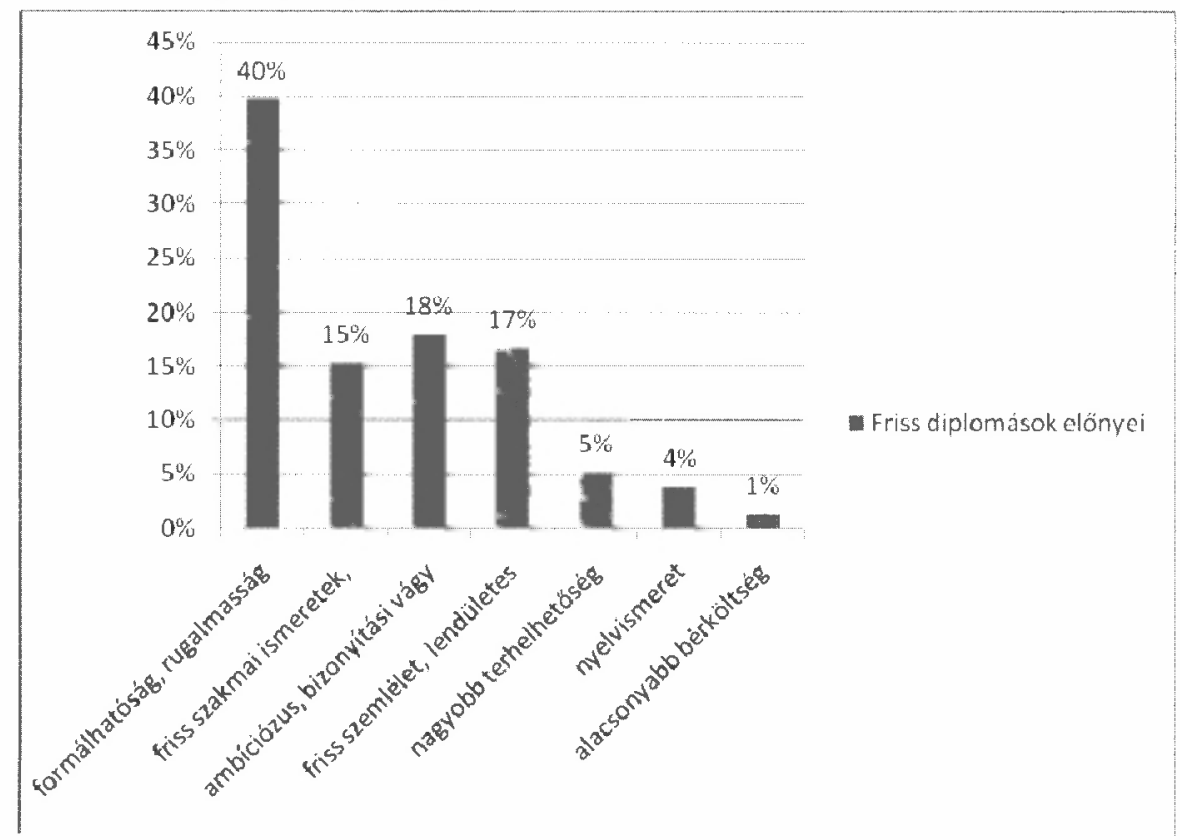

Forrás: Saját szerkesztés.

Hátrányként alapvetően a szakmai tapasztalat és a gyakorlat hiányát emelték ki jelentős mértékben, míg a többi szempont csak sokkal kisebb súllyal szerepelt (4. ábra). A formálhatósággal szemben hátrány, hogy relatíve sok energiát igényel a cég részéröl az új munkatárs betanítása, amely sokszor nem térül meg, hiszen erre a korcsoportra jellemző a magasabb fluktuáció. Hátrányként említették továbbá a 
túlzott bérigényt, a vállalkozói szemlélet hiányát, a csapatmunkában való dolgozás képességének, illetve a szakmával szembeni alázatnak a hiányát.

\section{4. ÁBRA}

Friss diplomások hátrányai az adott válaszok arányában

(The Disadvantages of Employing New Graduates, in the Ratio of the Given Answers)

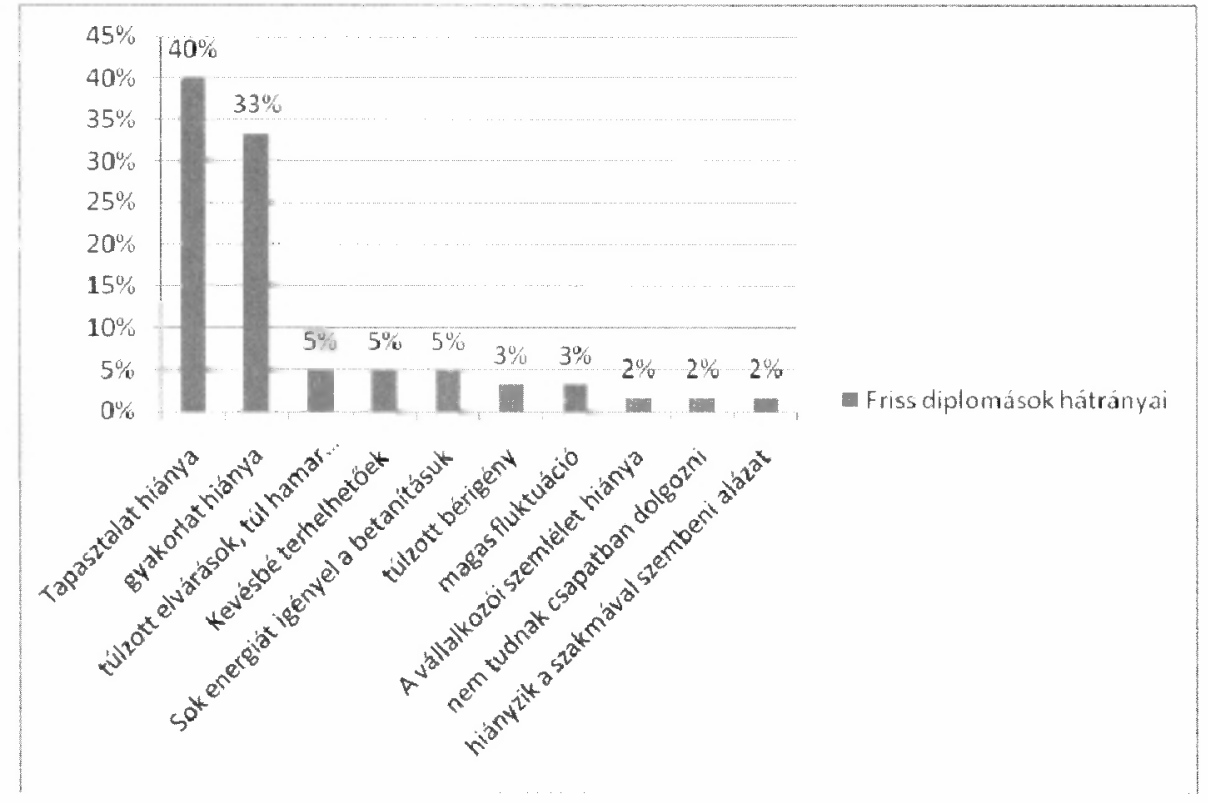

Forrás: Saját szerkesztés.

\section{TÁBLÁZAT}

A diplomás pályakezdók bekerülésének módjai

(The Way of Employment of the Graduated Entrants)

\begin{tabular}{lc}
\hline \multicolumn{1}{c}{ Felvétel módja } & Válaszok aránya \\
\hline egyéb meghirdetés alapján & $31 \%$ \\
gyakornoki programon keresztül & $23 \%$ \\
személyes kapcsolatokon keresztuil & $17 \%$ \\
karrier irodán keresztül & $10 \%$ \\
egyéb úton & $6 \%$ \\
munkaerő közvetítő cégeken keresztül & $5 \%$ \\
egyéb intézményi koordinátorok segítségével & $4 \%$ \\
intézményi közös projektek alapján & $3 \%$ \\
\hline
\end{tabular}

Forrás: Saját szerkesztés. 
Kovács Zsolt - Tamándl László - Filep Bálint : Észak-dunántúli vállalkozói elit elvárásai a Széchenyi István Egyetemmel és hallgatóival szemben. - Tér és Társadalom 24. évf. 2010/2. 93-105. p.

TÉT XXIV. évf. 2010 - 2

Észak-dunántúli vállalkozói elit .... 103

A friss diplomások számára meghirdetett pozíciókat legjellemzőbben a válaszadók egyéb meghirdetés útján töltik be (3. táblázat). Ennek oka, hogy több olyan szervezet is szerepel a mintában, melynek törvényi kötelessége hivatalosan meghirdetnie pozícióit. Második helyen a gyakornoki program szerepel, amely lehetőséget biztosít mind a hallgató, mind pedig a munkáltató számára, hogy kölcsönösen megismerjék egymást, így a diplomaszerzést követően már könnyebb a felvételi döntés. Ki kell emelnünk, hogy a vállalatok, cégek egyre inkább hajlanának efelé, hiszen a javasolt együttmüködési lehetőségek között kiemelten említik az Egyetemmel közös gyakornoki programokat.

\begin{tabular}{|c|c|}
\hline \multicolumn{2}{|c|}{$\begin{array}{l}\text { 4. TÁBLÁZAT } \\
\text { Pályakezdôkkel szemben támasztott elvárások } \\
\text { (The Expectations towards the Entrants) }\end{array}$} \\
\hline Elvárások & Válaszok aránya (\%) \\
\hline szaktudás & 15,2 \\
\hline megbízható nyelvtudás & 13,6 \\
\hline jó kommunikációs készség & 12,0 \\
\hline csapatmunka & 8,0 \\
\hline motiváció & 6,4 \\
\hline nyitott gondolkodás, új ismeretek iránti igény & 5,6 \\
\hline jó problémamegoldó képesség & 4,8 \\
\hline terhelhetőség & 4,0 \\
\hline precizitás, pontosság & 4,0 \\
\hline önmagát fejleszteni tudó munkatárs & 3,2 \\
\hline önállóság & 3,2 \\
\hline rugalmasság & 2,4 \\
\hline pozitív hozzáállás & 2,4 \\
\hline szorgalom & 2,4 \\
\hline kreativitás & 1,6 \\
\hline lojalitás & 1,6 \\
\hline alkalmazkodó képesség & 1,6 \\
\hline határozottság & 1,6 \\
\hline kapcsolatteremtő készség & 1,6 \\
\hline alázat & 1,6 \\
\hline mobilitás & 0,8 \\
\hline konfliktuskezelési képesség & 0,8 \\
\hline stressz-türő képesség & 0,8 \\
\hline megjelenés & 0,8 \\
\hline
\end{tabular}

Forrás: Saját szerkesztés. 
Kovács Zsolt - Tamándl László - Filep Bálint : Észak-dunántúli vállalkozói elit elvárásai a Széchenyi István Egyetemmel és hallgatóival szemben. - Tér és Társadalom 24. évf. 2010/2. 93-105. p.

A diplomás pályakezdőkkel szemben támasztott elvárásokat a 4. táblázat tartalmazza. Jól látható, hogy a válaszok alapján a megfelelő szakmai ismeretek, ahogy a legtöbbször fogalmaztak ,jó szakmai alap" szükséges, továbbá használható nyelvtudás, jó kommunikációs készség, csapatmunka, motiváció és nyitott gondolkodás, az új ismeretek utáni igény jelennek meg. Ezen felül a válaszok között elhangzott rengeteg készség és képesség, melyeknek viszont csak kisebb súlyt adtak.

Ha összehasonlítjuk az elvárásokat a pályakezdők előnyeivel és hátrányaival, akkor látható, hogy a szakmai tudás, mint elvárás az elónyök között megjelenik, azaz e feltétel talán többé-kevésbé teljesül. A nyelvtudás esetében már nem ilyen egyértelmủ a helyzet. Bár komoly elvárásként fogalmazódik meg, az előnyök között csak igen kis súllyal szerepel, ami azt jelenti, hogy a diplomás pályakezdők nyelvtudásával a munkáltatók nem igazán vannak megelégedve. A kommunikációs készséggel csak mint elvárás találkozunk, se elönyként, se hátrányként nem említik a válaszadók, míg a csapatmunkában való együttmüködés képessége, ha kis súllyal is, de a hátrányok között jelenik meg, amely szerint ezen készséget legtöbben nem birtokolják. A motiváció, friss és nyitott szemlélet egyértelmü előnyük a diplomás pályakezdőknek, amelyet el is várnak tőlük.

A munkáltatók továbbá kiemelték előnyként a pályakezdők formálhatóságát, rugalmasságát, amit alátámasztanak válaszaik, amelyeket arra a kérdésünkre adtak, hogy kész munkaerőt várnak-e, vagy inkább saját maguk tanítják be őket. A válaszadók 90\%-a nyilatkozott úgy, hogy nem vár kész munkaerőt, bár sokszor elhangzott, hogy jó lenne, de a gyakorlatban ez nem müködik, ezért inkább készek betanítani, s csak 10\%-uk véli úgy, hogy vagy nem szeretné, vagy nincs ideje és energiája betanítani az új munkatársat, ezért olyant keres, aki nagyon rövid időn belül 100\%-os munkatársként tud teljesíteni.

A Bolognai-rendszerre való átállásról és annak tapasztalatairól a szervezetek képviselői válaszaik alapján öt csoportba sorolhatók. A legnépesebb csoport, a válaszadók $64 \%$-a, nem rendelkezik tapasztalattal, nem tudott érdemben válaszolni a kérdésre. Ötödük teljesen negatívnak látja a rendszert, és úgy gondolják, hogy a mostani végzettek mind szakmai, mind gyakorlati szempontból gyengébbek elődeiknél. A kredit rendszer áltál „,megszủnt”, de legalábbis felpuhult a képzés időbeli korlátja, ami a munkahelyen is érződik, hiszen nehezebben tudják a határidőket betartani. A BSc-s képzésekkel kapcsolatban a müszaki képzésterületet leszámítva további negatív véleményeket fogalmaztak meg. A BSc/Ba képzések tantervéből hiányolják a kötelező szakmai gyakorlatot, kivétel egy-két képzés, amely ezt tartalmazza. $\mathrm{Az}$ új képzéseken végzett hallgatókat mind szakmailag, mind pedig gyakorlati tapasztalat szempontjából rosszabbnak ítéli az egyik markánsan negatív véleményt megfogalmazó. A megkérdezettek 6\%-a egyetért a rendszer alapelveivel, de a megvalósítással már nem, s a hibákat nem igazán a bolognai folyamatnak, mint inkább a magyar oktatási rendszer gyengeségeinek tudják be. Mindössze 6\%-uk nem érzékel különbséget a régi és az új rendszer között, illetve $4 \%$ abszolút pozitívan értékeli a változást. Ez az általánosan elmondható hiányos ismeret, illetve negatív megítélés visszaköszön a már említett Állami Számvevőszéki jelentésböl: „,a bolognai képzési rendszer elfogadottsága munkaadói oldalról bizonytalan és ismerethiányos" (ÁSZ 2009, 17). 
Kovács Zsolt - Tamándl László - Filep Bálint : Észak-dunántúli vállalkozói elit elvárásai a Széchenyi István Egyetemmel és hallgatóival szemben. - Tér és Társadalom 24. évf. 2010/2. 93-105. p.

TÉT XXIV. évf. 2010 - 2

Észak-dunántúli vállalkozói elit ....

105

\section{Irodalom}

ÁSZ (2009) Jelentés a felsőoktatási törvény végrehajtásának ellenőrzéséröl. Állami Számvevőszék, Budapest.

Boucher, G.-Conway, Ch.-Meer, van der E. (2003) Tiers of Engagement by Universities in their Region's Development. - Regional Studies. 9. 887-897. o.

Diplomás pályakezdók és egyetemi, föiskolai karok vállalati szemszögból - 2007. (2007) GVI Kutatási Füzetek. 1. Magyar Kereskedelmi és Iparkamara Gazdaság- és Vállalkozáselemző Intézet, Budapest.

Horváth D. (2008) Hazai gyakorlatok a diplomás pályakövetésben. - Fábri I.-Horváth T.-Kiss L.Nyerges A. (szerk.) Diplomás pályakövetés 1. Hazai és nemzetközi tendenciák. Educatio Társadalmi Szolgáltató Kht. - Országos Felsőoktatási Információs Központ, Budapest. 9-51. o.

Kasza G. (2007) Változó regionális szerepben a felsőoktatás. - Felsőoktatási Mühely. 1. 59-68. o.

Kuráth G. (2007) A hazai felsỏoktatási intézmények regionális hatásának vizsgálata a beiskolázási marketingmunkában. - Tér és Társadalom. 4. 95-129. o.

Majó Z. (2000) A felsőoktatás és a munkaeröpiac kapcsolata. - Farkas B.-Lengyel I. (szerk.) Versenyképesség - regionális versenyképesség. SZTE Gazdaságtudományi Kar Közleményei. JATEPress, Szeged. $169-186,0$.

Rechnitzer J.-Hardi T. (szerk.) (2003) A Széchenyi Istuán Egyetem hatása a régió fejlödésére. Tudományos Füzetek V. kötet. Széchenyi István Egyetem Gazdaság és Társadalomtudományi Intézete, Győr.

Rechnitzer J.-Smahó M. (szerk.) (2008) Unirégió. Egyetemek a határ menti együttmüködésben. MTA RKK, Pécs-Györ.

Tamándl L. (2008) Diplomás Palyakövetö Rendszer felmérései. Felmérés a végzös hallgatók körében 2008. Széchenyi István Egyetem Karrier és Öregdiák Iroda, Györ.

\section{THE EXPECTATIONS OF THE NORTH-TRANSDANUBIAN BUSI- NESS ELITE TOWARDS THE ISTVÁN SZÉCHENYI UNIVERSITY AND ITS STUDENTS}

\section{ZSOLT KOVÁCS - LÁSZLÓ TAMÁNDL - BÁLINT FILEP}

The higher education is one of the factors on the way to become elit, but nowadays it's receiving more and more criticism. Mass education, devalued degrees have made this factor less influential. In our essey we are dealing with this phenomenon through the results of an concrete research. The investigation completed through the cooperation between the Széchenyi István University and the Educatio Kht. is based on depth interwievs conducted by employers. The study in question analyses the role of the institutional factors and the role of the regionality concerning the features of employment of the entrants. As a result of the investigation - as expected from employer's research - we are given a full picture concerning the employer's - functioning in the university area - requirements and experiences related to the entrants, concerning the requirements of the institutional cooperation, moreover conceming the importance of the regional aspects. The aim of the pilot research is to build up a research program model that specifies and illustrates those steps and methodological considerations that are aimed to give a hand for the higher education institutions to make career examinations in the employer environment relevant to them. On the other hand the intention of the research is to make more theoretical conclusions concerning the relationship of the labour market and the regionality. 